\title{
Water and Wastewater Disinfection with Peracetic Acid and UV Radiation and Using Advanced Oxidative Process PAA/UV
}

\author{
Jeanette Beber de Souza, ${ }^{1}$ Fernanda Queiroz Valdez, ${ }^{2}$ Rhuan Felipe Jeranoski, ${ }^{1}$ \\ Carlos Magno de Sousa Vidal, ${ }^{1}$ and Grasiele Soares Cavallini ${ }^{3}$ \\ ${ }^{1}$ Department of Environmental Engineering, Universidade Estadual do Centro-Oeste, PR 153, km 07, Riozinho, P.O. Box 21, \\ 84500-000 Irati, PR, Brazil \\ ${ }^{2}$ Department of Hydraulics and Sanitation, the São Carlos Engineering School, São Paulo University, P.O. Box 359, \\ 13566-590 São Carlos, SP, Brazil \\ ${ }^{3}$ Department of Environmental Chemistry, Federal University of Tocantins (UFT), Campus Gurupi, P.O. Box 66, \\ 77402-970 Gurupi, TO, Brazil
}

Correspondence should be addressed to Jeanette Beber de Souza; jeanettebeber@yahoo.com.br

Received 6 October 2014; Revised 14 December 2014; Accepted 28 December 2014

Academic Editor: Meenakshisundaram Swaminathan

Copyright (C) 2015 Jeanette Beber de Souza et al. This is an open access article distributed under the Creative Commons Attribution License, which permits unrestricted use, distribution, and reproduction in any medium, provided the original work is properly cited.

The individual methods of disinfection peracetic acid (PAA) and UV radiation and combined process PAA/UV in water (synthetic) and sanitary wastewater were employed to verify the individual and combined action of these advanced oxidative processes on the effectiveness of inactivation of microorganisms indicators of fecal contamination E. coli, total coliforms (in the case of sanitary wastewater), and coliphages (such as virus indicators). Under the experimental conditions investigated, doses of 2,3 , and $4 \mathrm{mg} / \mathrm{L}$ of PAA and contact time of 10 minutes and 60 and 90 s exposure to UV radiation, the results indicated that the combined method PAA/UV provided superior efficacy when compared to individual methods of disinfection.

\section{Introduction}

Waters that do not present good quality represent a menace to the human health, due to the possibility of contamination of populations through waterborne diseases. According to the Trata Brasil Institute, $88 \%$ of the deaths caused by diarrhea worldwide are caused by unsuitable sanitation. In 2011, in Brazil, 396.048 people were infected with diarrhea, and 35\% of these patients were children under 5 years old [1].

One of the main sources of water contamination is the release of raw domestic sewage or wastewater that have not undergone efficient treatment, thus constituting a potential load of pathogenic organisms excreted by infected individuals $[2,3]$.

In such context, the interest in wastewater disinfection processes has become increasingly higher.

Chlorine is the most widely employed disinfectant to treat water and wastewater all over the world. This is due to its largely known technology, low cost, and proved efficiency in inactivating a great variety of pathogenic microorganisms [35].

However, the use of chlorine to disinfect sanitary sewage requires dechlorination prior to the effluent release in the receptor body; even at low concentrations, chlorine is toxic to the water life. Regarding drinking water, there is a concern about this disinfectant oxidizing some kinds of organic matter, mainly humic and fulvic acids, and forming trihalomethanes, which are highly carcinogenic compounds $[5,6]$.

Due to this problem, new studies have been developed, seeking alternative disinfectants to the chlorine, such as ultraviolet (UV) radiation, peracetic acid (PAA), and advanced oxidative processes as the PAA/UV proposal analyzed in this study.

$\mathrm{UV}$ radiation is a physical mechanism that transfers electromagnetic energy to the microorganisms' genetic material, through special mercury vapor lamps. When the UV radiation penetrates the cell wall, it destroys the microorganism ability to reproduce [7]. 
UV radiation presents the advantages of being efficient to inactivate a great variety of microorganisms without provoking residual effects that might be harmful to human being or water life; it is easy to operate and requires short contact time for disinfection, which implies smaller units in the water or wastewater treatment plants [7].

However, small doses might not be efficient in inactivating some viruses, spores, and cysts, and some organisms might reverse the radiation effect through the photoreactivation or dark repair. Besides that, turbidity and total suspended solids present in the sewage might reduce the efficacy of disinfection through radiation. And, regarding drinking water, the main inconvenience is the absence of disinfectant residual along the distribution system. UV radiation is more expensive than chlorination, but the costs become competitive when dechlorination is taken into consideration $[4,6,7]$.

Peracetic acid $\left(\mathrm{CH}_{3} \mathrm{CO}_{3} \mathrm{H}\right)$ is a strong oxidant which presents advantages: the treatment being easy to implement (without the need of high investment), the large spectrum of microbial activity even in the presence of heterogeneous organic matter, absence of residual or toxic and/or mutagenic by-products, not requiring dechlorination, presenting low dependency on $\mathrm{pH}$, and short contact time [8].

There are no reports in the literature pointing PAA as carcinogenic or that it presents toxicity in the reproduction and human development.

When surveying studies on the use of PAA to disinfect wastewater, Cavallini et al. [9] observed that the toxicity results and the formation of by-products were very low when compared with chlorine, which might be ascribed to the PAA composition and its fast decomposition in the effluent.

The disadvantages of using PAA in wastewater disinfection are the increase in the effluent organic content, enhancing microbial regrowth, higher cost when compared to chloride and lower efficiency against some viruses and parasites $[8,10]$, and, in water disinfection, the absence of disinfectant residual.

In the literature, some advanced oxidative processes (AOPs) have been proposed $\left(\mathrm{UV} / \mathrm{H}_{2} \mathrm{O}_{2}, \mathrm{O}_{3} / \mathrm{H}_{2} \mathrm{O}_{2}, \mathrm{O}_{3} / \mathrm{UV}\right.$, and $\left.\mathrm{TiO}_{2} / \mathrm{UV}\right)$. The AOPs are based on the use of secondary oxidants, such as free radicals $(\mathrm{OH})$, which can be generated by the interaction of UV radiation with a chemical disinfectant able to release such radicals. Hydroxyl radicals are highly reactive oxidant agents which can be used to oxidize organic and inorganic compounds and other toxic or pollutants or resistant to biological treatment and as disinfectants [11, 12].

In the PAA/UV sequential process there is PAA photolysis under the action of the UV light. According to Caretti and Lubello [11] there is an interruption in the bond $\mathrm{O}-\mathrm{O}$ of the PAA molecule, with the subsequent formation of the hydroxyl radical. The presence of PAA hydrogen contributes not only to the formation of PAA again as soon as it is consumed, but also to the formation of new hydroxyl radicals.

The use of two or more disinfectants, simultaneously or sequentially applied, characterizes the disinfection method named by USEPA [7] as interactive or combined and presents the increase in microbial inactivation efficiency in some groups of microorganisms as an advantage; this includes the possibility of synergism to occur, minimization of disinfection by-products formation, and the use of smaller doses of disinfectant agents.

The sublethal damage to the cell wall of the microorganism provided by a disinfecting agent can improve the sensitivity of the organism to the action of other disinfectants and then synergism occurs.

However, despite the promising advantages of the use of combined processes, they do not present global improvement of disinfection in all situations. Thus, research in this area, involving different disinfection methods in combination, as it is the case of PAA/UV in different groups of indicator microorganisms, is highly relevant.

This study presents tests with wastewater and synthetic water disinfection using peracetic acid (PAA), UV radiation and employing the sequential PAA/UV process to the inactivation of indicator microorganisms: E. coli, total coliforms, and coliphages.

\section{Materials and Methods}

2.1. Experimental Conditions. Disinfection experiments, both in water and in wastewater, were carried out individually with PAA, UV radiation and using the sequential PAA/UV method. The individual assays with PAA and UV radiation were performed in order to calculate the synergism, once the method employed takes into account individual disinfection tests, as will be seen in Section 3.

The water under study, named synthetic water, was composed of deionized water and specific salts, according to the Standard Methods for the Examination of Water and Wastewater [13], and added to the indicator microorganisms strains: E. coli strain ATCC 11229 (bacteria indicator) and coliphages (virus indicator) isolated from wastewater, using the E. coli CIP 55.30 as the host strain.

The wastewater was collected at the output of a municipal wastewater treatment plant (WTP) consisting of a biological secondary treatment: a fluidized bed anaerobic reactor (FBAR) and an upflow anaerobic sludge blanket (UASB) in parallel, followed by stabilization pond, and the sewage samples were collected at the output of this pond.

For the UV radiation disinfection tests, a laboratory bench reactor measuring $45 \mathrm{~cm} \times 40 \mathrm{~cm} \times 15 \mathrm{~cm}$ was employed, operating in a batch mode, made of stainless steel, with removable aluminum lid, containing six emerged $15 \mathrm{~W}$ mercury vapor lamps.

The UV reactor was filled up with both effluent and synthetic water up to the point where liquid reached $4 \mathrm{~cm}$, which made up a total volume of 7,5 liters. In order to carry out the experiments, the six lamps in the reactor were turned on for 30 minutes in advance to produce heat and stabilize. The times of exposure employed were 60 and 90 seconds, which in experiments with wastewater characterized doses of 125,16 and $187,74 \mathrm{mWs} / \mathrm{cm}^{2}$ for test 1 and 109,89 and $164,84 \mathrm{mWs} / \mathrm{cm}^{2}$ for test 2 . Regarding the water experiments, the same times of exposure, 60 and $90 \mathrm{~s}$, characterized doses of 282,58 and $423,87 \mathrm{mWs} / \mathrm{cm}^{2}$, respectively, in test 1 and 217,71 and $326,56 \mathrm{mWs} / \mathrm{cm}^{2}$ in test 2 . 
TABLE 1: E. coli, TC, and coliphages inactivation employing, individually, PAA and UV radiation in tests with wastewater.

\begin{tabular}{|c|c|c|c|c|c|c|c|}
\hline & & \multirow{3}{*}{$N_{o}$} & \multicolumn{3}{|c|}{ Peracetic acid } & \multirow{2}{*}{\multicolumn{2}{|c|}{$\begin{array}{l}\text { UV radiation } \\
\text { Exposure (s) }\end{array}$}} \\
\hline & & & \multicolumn{3}{|c|}{ Concentration $(\mathrm{mg} / \mathrm{L})$} & & \\
\hline & & & 2 & 3 & 4 & 60 & 90 \\
\hline \multirow{3}{*}{ Test 1} & E. coli & $1,1 \times 10^{4}$ & $3,4 \times 10^{3}$ & $3,7 \times 10^{3}$ & $1,3 \times 10^{2}$ & 6 & 4 \\
\hline & TC & $2,25 \times 10^{5}$ & $7 \times 10^{4}$ & $2,12 \times 10^{4}$ & $6,2 \times 10^{3}$ & $5,1 \times 10^{3}$ & $3,9 \times 10^{3}$ \\
\hline & Coliphages & $3,15 \times 10^{2}$ & $1,35 \times 10^{2}$ & $1,25 \times 10^{2}$ & $2,4 \times 10^{2}$ & 5 & 10 \\
\hline \multirow{3}{*}{ Test 2} & E. coli & $3 \times 10^{4}$ & - & $<1$ & - & 10 & 10 \\
\hline & $\mathrm{TC}$ & $3,6 \times 10^{5}$ & - & $5,2 \times 10^{4}$ & - & 200 & 160 \\
\hline & Coliphages & $1,27 \times 10^{3}$ & - & 320 & - & $<1$ & $<1$ \\
\hline
\end{tabular}

-: not carried out; $<1$ : lower than the detection limit of the method used.

Throughout the exposure time, the liquid was kept under magnetic agitation, preventing the sedimentation of solids. After the exposure time was over, samples were collected for the microbiological examination.

Radiation intensity measurements were carried out with a radiometer (Vilber Lourmat) with UV radiation detector sensor at the $254 \mathrm{~nm}$ wavelength. To determine the UV radiation dose, the route described by Daniel [14], as well as the study carried out by Souza et al. [15], was followed.

PAA disinfection tests were carried out in a batch mode employing the commercial product PROXITANE 1512 which is a quaternary mixture in equilibrium containing peracetic acid (15\%), hydrogen peroxide (23\%), acetic acid (16\%), and stabilizing vehicle. In the experiments with wastewater, PAA doses applied were 2,3 , and $4 \mathrm{mg} / \mathrm{L}$ in test 1 and $3 \mathrm{mg} / \mathrm{L}$ in test 2; the contact time employed was 10 minutes for all doses. In experiments with water, in both tests carried out, PAA doses employed were 2,3 , and $4 \mathrm{mg} / \mathrm{L}$ and contact time was 10 minutes. To inactivate the residual PAA, after the contact time specified, sodium thiosulfate (1\%) was added at the proportion $0,1 \mathrm{~mL}$ for each $100 \mathrm{~mL}$ sample. The residual PAA was measured through the spectrophotometric method, using the chromophore $\mathrm{N}, \mathrm{N}$-diethyl-p-phenylenediamine (DPD) $\left(\left(\mathrm{C}_{2} \mathrm{H}_{5}\right)_{2} \mathrm{C}_{6} \mathrm{H}_{4} \mathrm{NH}_{2}, 97 \%\right.$ ALDRICH $)$ [9].

In the combined method, the same procedures were employed as the individual methods, PAA was the primary disinfectant employed, and, after the contact time, the effluent was exposed to the previously set UV radiation doses.

2.2. Sample Characterization. The physicochemical characterization of samples was carried out according to the procedures indicated in the Standard Methods for the Examination of Water and Wastewater [13], and turbidity, total suspended solids, chemical oxygen demand (COD), and absorbance $254 \mathrm{~nm}$ analyses were performed for the wastewater and turbidity, pH, COD, and absorbance $254 \mathrm{~nm}$, for the water. Besides that, total coliforms, E. coli, and coliphages were quantified in the wastewater and E. coli and coliphages in water.

In order to quantify E. coli and total coliforms (TC) the membrane filtration technique was employed using the culture medium Agar Hicrome Selective ECC Base CAT.M1294 (Himedia) which enables the simultaneous determination of total coliforms and E. coli.
For the quantification of coliphages, the plates test was carried out according to the CETESB L5.225 Norm [16] and the culture medium employed was modified Tryptic Soy Agar (TSA).

\section{Results and Discussion}

3.1. Tests of Wastewater Disinfection Employing the PAA and UV Radiation Individual Methods. For the wastewater, results of the physicochemical analyses of turbidity, SST, COD, and absorbance $254 \mathrm{~nm}$ varied, respectively, from 8,43 to $71,7 \mathrm{NTU}, 15$ to $140 \mathrm{mg} / \mathrm{L}, 53$ to $164 \mathrm{mg} / \mathrm{L}$, and 0,313 to 0,364 from the first to the second test.

In Table 1 the results of microbial inactivation employing the PAA and UV individual methods are presented, and for the inactivation calculation the equation $-\log \left(N / N_{o}\right)$ was used, where $N_{o}$ corresponds to the microorganisms initial number (gross sample) and $N$ the microorganisms after disinfection.

In relation to the results in UV tests, good global efficiency inactivation was observed in test 2 , reaching $3,48 \log$ E. coli inactivation values for both doses of UV used, 3,1 log coliphages, also for both UV doses, and 3,35 log total coliforms for the $164,84 \mathrm{mWs} / \mathrm{cm}^{2}$ dose.

In test 1 , despite the coliphages inactivation presenting lower values, its inactivation was efficient (Table 1). This is due to the fact that the coliphages concentration in the gross effluent was not really high. On the other hand, in the same test, UV radiation was not very efficient to remove total coliforms (maximum inactivation $\log 1,76$ ). The biggest difficulty to the inactivation of total coliforms is also observed in several other studies in the area specific literature, including Souza et al. [15].

In test 2 , although the effluent turbidity was much higher than in test 1 , the UV disinfection did not have its efficiency reduced in this case.

In relation to the inactivation of indicator microorganisms E. coli, TC, and coliphages, in both PAA tests and with all doses applied, inactivation below $2 \log$ was observed for all microorganisms, except for the E. coli in the second test, in which 4,48 log was observed. Regarding specifically the coliphages Souza and Daniel [17] also observed results of low inactivation of such viral indicators, employing 3 and $4 \mathrm{mg} / \mathrm{L}$ PAA concentrations and 20-minute contact time. 
TABle 2: E. coli, TC, and coliphages inactivation, employing the PAA/UV sequential method in tests with wastewater.

\begin{tabular}{ccccccccc}
\hline & & \multirow{2}{*}{$N_{o}$} & \multicolumn{5}{c}{ Sequential PAA/UV } \\
& & & $2(60)$ & $2(90)$ & $3(60)$ & $3(90)$ & $4(60)$ & $4(90)$ \\
\hline \multirow{2}{*}{ Test 1} & E. coli & $1,1 \times 10^{4}$ & 410 & 7 & 5 & $<1$ & $<1$ \\
& TC & $2,25 \times 10^{5}$ & $2,24 \times 10^{4}$ & $2,9 \times 10^{3}$ & $7,1 \times 10^{3}$ & $2,35 \times 10^{3}$ & $3,1 \times 10^{2}$ & $1,1 \times 10^{2}$ \\
& Coliphages & $3,15 \times 10^{2}$ & 10 & 5 & $<1$ & 5 & 5 & $<1$ \\
\hline \multirow{3}{*}{ Test 2} & E. coli & $3 \times 10^{4}$ & - & - & $<1$ & $<1$ & - \\
& TC & $3,6 \times 10^{5}$ & - & - & 140 & 20 & - & - \\
& Coliphages & $1,27 \times 10^{3}$ & - & - & $<1$ & $<1$ & - \\
\hline
\end{tabular}

-: tests not carried out.

Gehr et al. [18] who analyzed different disinfection processes, amongst them PAA, ozone, and UV radiation, to treat effluents in a municipal WTP which employed physicochemical treatment (ferric coagulation or with aluminum) to treat domestic and industrial effluents altogether observed high negative influence of the organic matter on the PAA disinfection, even making the adoption of PAA in this case unviable as an alternative disinfectant for the STS under study. It is important to highlight that in that study all sewage samples presented high concentrations of dissolved organic carbon (DOC) (124-240 mg/L), SS (16-45 mg/L), and turbidity (16-31 NTU).

Regarding PAA tests, samples were collected for the analyses of COD and residual.

The PAA residual, after 10-minute contact, was low; it varied from $<0,1$ to $0,92 \mathrm{mg} / \mathrm{L}$ in test 1 and was $0,34 \mathrm{mg} / \mathrm{L}$ in test 2 , indicating that a considerable part of the PAA applied was consumed in the wastewater oxidation/disinfection phases. After disinfection with PAA, the COD increased with the increase in the concentration of the PAA applied (in test 1, e.g., from $53 \mathrm{mg} / \mathrm{L}$ in gross sewage to $70 \mathrm{mg} / \mathrm{L}$ after application of $4 \mathrm{mg} / \mathrm{L}$ PAA). This fact was observed in other studies developed by the authors of this study, with special attention to the study of Cavallini et al. [19] who analyzed the disinfection of wastewater with PAA and observed that the application of different PAA doses to the wastewater with 20minute contact time resulted in $15 \%$ average increase in the COD at each $10 \mathrm{mg} / \mathrm{L}$ PAA applied.

According to Kitis [8] the increase in organic content in the PAA disinfected sewage samples, associated with the microbial potential regrowth, is the biggest inconvenience of the use of this disinfectant. The author ascribes this increase to the presence of acetic acid, which is a biodegradable compound, present both in the PAA composition and in its decomposition product.

However, the authors of this work do not ascribe the COD elevation only to the acetic acid, as proposed by Kitis [8], once the PAA is a percarboxylic acid which also contributes to the organic load of the disinfected effluent. Thus, it is not possible to relate the COD elevation only to the acetic acid.

3.2. PAA/UV Sequential Disinfection of Wastewater. In Table 2, results obtained with the PAA/UV sequential method in both tests with wastewater are presented.
For E. coli 4,5 log inactivation was obtained for both PAA/UV doses employed in experiment 2, in which $100 \%$ inactivation was reached. Also, for the three last combined doses employed of $3(187,74), 4(125,16)$, and $4(187,74)$, despite the lower inactivation $\log (4,04), 100 \%$ E. coli inactivation efficiency was also reached.

For total coliforms, inactivation of up to 4,25 log with the $4(187,74)$ dose was obtained, and, for coliphages, 3,1 log inactivation for both doses applied in experiment 2, and 2,5 log for doses $3(125,16)$ and $4(187,74)$ employed in experiment 1 .

In general, disinfection tests with the sequential method were proved more efficient than the experiments in which disinfectants were used separately. In most cases, the highest inactivation log reached using only one disinfectant was overcome in the sequential method with the use of smaller doses of each disinfectant. This result demonstrates that the sequential method can bring economic benefit, once the doses needed of each disinfectant were smaller in this process than in the disinfection with only PAA or only UV radiation.

3.3. Synergy Verification. With the inactivation results of the sequential disinfection tests, it was possible to verify the occurrence or nonoccurrence of synergy for the method used. According to Finch et al. [20], synergy is verified from the premise that the inactivation resulting from the sequential action must be higher than the sum of individual inactivation. Consider

$$
\text { Synergy }=I_{r}-\left(I_{1}+I_{2}\right), \quad I=-\log \left(\frac{N}{N_{o}}\right),
$$

where $I_{r}$ is sequential process resulting inactivation, $I_{1}$ is primary disinfectant resulting inactivation, $I_{2}$ is secondary disinfectant resulting inactivation, $N$ is organism final number, and $N_{o}$ is organism initial number.

Results of synergy verification for both tests are presented in Table 3.

According to the results obtained, very little synergy was observed, occurring only for the $E$. coli with the dose $3(187,74)$ and for coliphages with the doses $3(125,16)$ and $1(187,74)$, in the first test. And, in test 2, there was synergy only in the inactivation of total coliforms, with the dose $3(164,84)$. That is, in most cases, the inactivation provided by the sequential method was lower than the sum of inactivation in the individual disinfection processes. 
TABLE 3: Synergy verification.

\begin{tabular}{lcccccccc}
\hline & \multicolumn{9}{c}{ Doses APA/UV } \\
& \multicolumn{1}{c}{ Test 1 } & \multicolumn{2}{c}{ Test 2 } \\
& $2(125,16)$ & $2(187,74)$ & $3(125,16)$ & $3(187,74)$ & $4(125,16)$ & $4(187,74)$ & $3(109,89)$ & $3(164,84)$ \\
\hline E. coli & $-2,34$ & $-0,75$ & $-0,39$ & 0,13 & $-1,15$ & $-1,33$ & $-3,48$ & $-3,48$ \\
TC & $-1,15$ & $-0,38$ & $-1,16$ & $-0,8$ & $-0,34$ & $-0,01$ & $-0,68$ & 0,06 \\
Coliphages & $-0,66$ & $-0,06$ & 0,3 & $-0,1$ & $-0,12$ & 0,88 & $-0,6$ & $-0,6$ \\
\hline
\end{tabular}

TABLE 4: E. coli and coliphages inactivation employing PAA and UV radiation individually in tests with water.

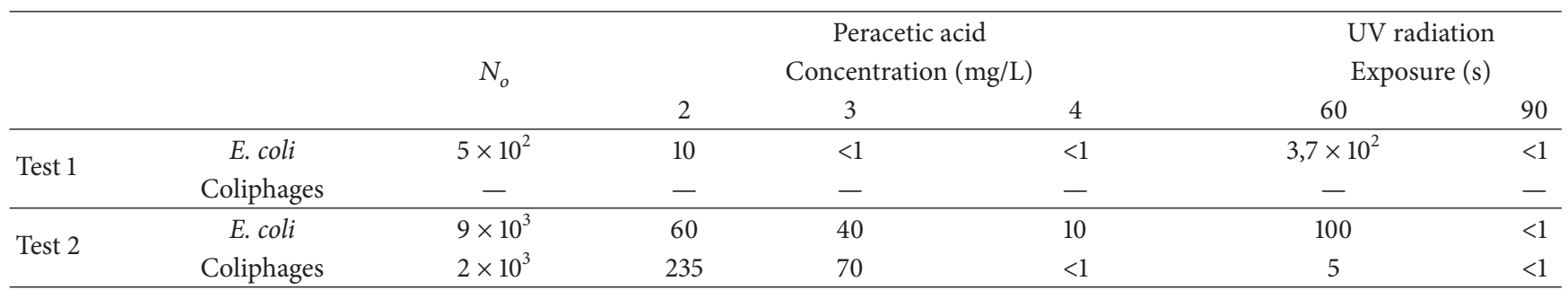

$N_{o}$ : microorganisms initial number in gross water; -: test not carried out.

However, although the sequential method almost did not present synergy, it was proved more efficient in the disinfection than the individual methods. The sequential method provided higher inactivation values obtained amongst the three methods analyzed, and these are 4,48 log for E. coli, 4,25 $\log$ for total coliforms, and 3,1 log for coliphages.

In the case of wastewater experiments, the low residual value of PAA in the effluent did not permit the formation of AOP and its potential effect added to the microbial inactivation.

Caretti and Lubello [11] proposed an advanced treatment for wastewater, aiming at complete reuse in agriculture, and evaluated the efficiency of the PAA and UV disinfectants in the configuration: PAA/UV and UV/PAA, and, considering the same doses, observed that the levels of inactivation reached when the PAA was added before the UV radiation were higher. The effect of inactivation resulting from the PAA/UV method overcame the sum of these disinfectants individual effects, confirming the synergy between these two treatments. The highest efficiency of the PAA/UV combined method was ascribed to the formation of free radicals due to the PAA photolysis, in the presence of UV rays.

Koivunen and Heinonen-Tanski [12], with the PAA/UV combined method, observed synergic effects against enteric bacteria, reaching values over $2 \log$ inactivation for $E$. coli. However, the coliphages inactivation presented much lower synergy values.

3.4. Tests of Water Disinfection Employing the Individual Methods PAA and UV Radiation. Regarding the experiments with synthetic water, the turbidity was $0,52 \mathrm{NTU}$ in the first test and 0,82 in the second test; the COD varied between 367 and $377 \mathrm{mg} / \mathrm{L}$ in the first test and 655 and $665 \mathrm{mg} / \mathrm{L}$ in the second; the absorbance in $254 \mathrm{~nm}$ varied from 0,069 to 0,107 in the first test and 0,136 to 0,158 in the second.

High COD and absorbance values in the synthetic water were due to the cultures media present in the microorganism
TABLE 5: PAA residual in $\mathrm{mg} / \mathrm{L}$ for both tests with water.

\begin{tabular}{lcc}
\hline PAA applied & 1st test & 2nd test \\
concentration $(\mathrm{mg} / \mathrm{L})$ & 0 & 0 \\
0 & 0,75 & 0,2 \\
2 & 1,66 & 1,45 \\
3 & 2,4 & 2,11 \\
4
\end{tabular}

strains added to the water, which also provided higher turbidity to the water in test 2 , and the COD had its valued doubled, in test 2, proportionally to the elevation of E. coli concentration and coliphages in water prior to disinfection.

In Table 4, the results of microbial inactivation in the synthetic water disinfection tests employing the individual methods PAA and UV radiation are presented.

In test 1 the UV radiation provided $0,13 \log E$. coli inactivation after $60 \mathrm{~s}$ exposure and total efficacy at $90 \mathrm{~s}$, with approximately $2,7 \mathrm{log}$, with significant improvement of this microorganism inactivation being noted with the increase in the UV dose.

According to data presented in Table 4, the UV system was highly efficient in terms of $E$. coli and coliphages inactivation regarding the $90 \mathrm{~s}$ exposure time, in which radiation doses above $300 \mathrm{~mW} \cdot \mathrm{s} \cdot \mathrm{cm}^{-2}$ were generated for both tests.

In experiments with PAA in test 1 , the concentration of $2 \mathrm{mg} / \mathrm{L}$ PAA provided 1,7 log E. coli inactivation and for the concentrations 3 and $4 \mathrm{mg} / \mathrm{L}$ total inactivation was reached (2,7 log). Regarding the second test, only the dose $4 \mathrm{mg} / \mathrm{L}$ resulted in coliphages maximum inactivation $(3,3 \mathrm{log})$ and 2,95 log for E. coli.

In Table 5, PAA residuals present in samples after disinfection for the different doses applied are presented.

PAA was not totally consumed (after 10-minute contact time) at any of the concentrations applied; a certain pattern of PAA consumption was even observed: for doses 2, 3, 
TABLE 6: E. coli and coliphages inactivation with the sequential PAA/UV method with synthetic water.

\begin{tabular}{|c|c|c|c|c|}
\hline Concentration $(\mathrm{mg} / \mathrm{L})$ & Radiation contact time (s) & $\begin{array}{l}\text { E. coli inactivation } \\
{\left[-\log \left(N / N_{o}\right)\right]}\end{array}$ & $\begin{array}{c}\text { Coliphages inactivation } \\
{\left[-\log \left(N / N_{o}\right)\right]}\end{array}$ & PAA residual $(\mathrm{mg} / \mathrm{L})$ \\
\hline \multirow{3}{*}{2} & 0 & 2,17 & 0,93 & \multirow{3}{*}{0,1} \\
\hline & 60 & 5 & 5 & \\
\hline & 90 & 5 & 5 & \\
\hline \multirow{3}{*}{3} & 0 & 2,35 & 1,46 & \multirow{3}{*}{0,94} \\
\hline & 60 & 5 & 5 & \\
\hline & 90 & 5 & 5 & \\
\hline \multirow{3}{*}{4} & 0 & 2,95 & 5 & \multirow{3}{*}{1,58} \\
\hline & 60 & 5 & 5 & \\
\hline & 90 & 5 & 5 & \\
\hline
\end{tabular}

and $4 \mathrm{mg} / \mathrm{L}$ applied in the first test, the consumption was, respectively, 1,$25 ; 1,34$; and $1,6 \mathrm{mg} / \mathrm{L}$ PAA, and in the second test, which presented higher microorganisms density in the samples prior to disinfection, the PAA residual was lower, and the consumption was 1,$8 ; 1,55$; and $1,89 \mathrm{mg} / \mathrm{L}$, respectively, for the same doses previously employed. The PAA consumption, in this study, was always below $2 \mathrm{mg} / \mathrm{L}$, which seems to mean that only certain percentage of the PAA applied is really used to satisfy the demand and disinfect; the remaining PAA is available in residual form in the water or wastewater, not presenting antibacterial effect.

After this observation, it is important to highlight that the use of PAA in full scale, for different water or wastewater characteristics, requires the evaluation of its real consumption, which depends amongst other factors on the characteristics of the organic matter and the microbial density, so that the best dosage to be employed is set for each case, aiming to avoid, mainly, unnecessary costs with the use of chemical product.

3.5. Sequential PAA/UV Disinfection with Synthetic Water. In Table 6, the microorganisms E. coli and coliphages inactivation values in the sequential PAA/UV disinfection, as well as the PAA residual, are presented.

The E. coli and coliphages inactivation results with PAA treated water $(2,3$, and $4 \mathrm{mg} / \mathrm{L})$ followed by UV radiation were considered excellent, once 5 log microorganism reduction was reached with all combined doses employed, and in all situations the detection limit of the method employed was reached, after 60-second UV radiation exposure, suggesting that it is possible to reduce the UV radiation time.

As PAA residual was detected after the contact period of 10 minutes, the higher inactivation values obtained in this experiment are ascribed to the occurrence of $\mathrm{OH}$ radical formation provided by the AOP PAA/UV.

\section{Conclusion}

This study enabled us to conclude that the E. coli, TC, and coliphages microorganisms inactivation through the advanced PAA/UV oxidative process is an alternative which presents high efficacy of microbial inactivation once it resulted in maximum disinfection values. The absence of suspended solids in the synthetic water provided, in general, better microbial inactivation results when compared to the experiments carried out with wastewater. This is probably due to the shield effect provided by the suspended particles which protect the microorganisms from the action of the disinfectant agents, both chemical, and especially of the UV radiation.

The possibility of synergy occurrence when employing AOPs such as the PAA/UV proposal is a very important tool, which should be better investigated, as it can guarantee higher global disinfection efficacy even when lower doses of disinfectant are applied, which might lower the cost of the process. Although economic viability has not been evaluated in this study, it is a relevant aspect, mainly in the case of WTP; this factor might be the one to rule the disinfection systems maintenance in such units.

\section{Conflict of Interests}

The authors declare that there is no conflict of interests regarding the publication of this paper.

\section{References}

[1] Trata Brasil, Situação do Saneamento no Brasil, 2012, http:// www.tratabrasil.org.br/saneamento-no-brasil.

[2] J. B. Costa, Avaliação ecotoxicológica de efluente de tratamento secundário de esgoto sanitário após desinfecção com ácido peracético, cloro, ozônio e radiação ultravioleta [Tese de Doutorado], Escola de Engenharia de São Carlos, Universidade de São Paulo, São Carlos, Brazil, 2007.

[3] R. F. Gonçalves, Desinfecção de efluentes sanitários, vol. 1, PROSAB/FINEP, ABES, RiMa, Rio de Janeiro, Brazil, 2003.

[4] M. V. Sperling, Introdução a Qualidade das Águas e ao Tratamento de Esgotos, Universidade Federal de Minas Gerais, Belo Horizonte, Brazil, 3rd edition, 2005.

[5] USEPA-U.S. Environmental Protection Agency, Wastewater Technology Fact Sheet Chlorine Disinfection, Washington, DC, USA, 1999.

[6] N. Fischer, Sinergismo em desinfecção sequencial com aplicação de cloro e radiação ultravioleta, Monografia (Graduação em Engenharia Ambiental), Escola de Engenharia de São Carlos, Universidade de São Paulo, São Carlos, Brazil, 2010. 
[7] (USEPA) U.S. Environmental Protection Agency, Wastewater Technology Fact Sheet Ultraviolet Disinfection, USEPA, Washington, DC, USA, 1999.

[8] M. Kitis, "Disinfection of wastewater with peracetic acid: a review," Environment International, 2003, http://www.sciencedirect.com.

[9] G. S. Cavallini, S. X. Campos, J. B. Souza, and C. M. Vidal, "Utilização do ácido peracético na desinfecção de esgoto sanitário: uma revisão," Semina: Ciências Exatas e Tecnológicas, vol. 33, no. 1, pp. 27-40, 2012.

[10] J. B. Souza, Avaliação de métodos para desinfecção de água, empregando cloro, ácido peracético, ozônio e o processo de desinfecção combinado ozônio/cloro [Doutorado Tese em Hidráulica e Saneamento], Escola de Engenharia de São Carlos, Universidade de São Paulo, São Carlos, Brazil, 2006.

[11] C. Caretti and C. Lubello, "Wastewater disinfection with PAA and UV combined treatment: a pilot plant study," Water Research, vol. 37, no. 10, pp. 2365-2371, 2003.

[12] J. Koivunen and H. Heinonen-Tanski, "Inactivation of enteric microorganisms with chemical disinfectants, UV irradiation and combined chemical/UV treatments," Water Research, vol. 39, no. 8, pp. 1519-1526, 2005.

[13] APHA/AWWA/WEF, Standard Methods of the Examination of Water and Wastewater, CD-ROM, APHA (American Public Health Association), Washington, DC, USA, 20th edition, 1998.

[14] L. A. Daniel, Processos de desinfecção e desinfetantes alternativos na produção de água potável, PROSAB, São Paulo, Brazil, 2001.

[15] J. B. Souza, C. M. S. Vidal, G. S. Cavallini, L. Quartaroli, and L. R. C. Marcon, "Avaliação do emprego da radiação ultravioleta na desinfecção de esgoto sanitário," Semina: Ciências Exatas e Tecnológicas, vol. 33, no. 2, pp. 117-126, 2012.

[16] CETESB (Companhia de Tecnologia de Saneamento Ambiental), "Determinação de colifagos em amostras de água," Método de ensaio L5/225, CETESB, São Paulo, Brazil, 1990.

[17] J. B. Souza and L. A. Daniel, "Comparação entre hipoclorito de sódio e ácido peracético na inativação de E. coli, colifagos e C. perfringens em água com elevada concentração de matéria orgânica," Engenharia Sanitária e Ambiental, vol. 10, pp. 111-117, 2005.

[18] R. Gehr, M. Wagner, P. Veerasubramanian, and P. Payment, "Disinfection efficiency of peracetic acid, UV and ozone after enhanced primary treatment of municipal wastewater," Water Research, vol. 37, no. 19, pp. 4573-4586, 2003.

[19] G. S. Cavallini, S. X. de Campos, J. B. de Souza, and C. M. de Sousa Vidal, "Evaluation of the physical-chemical characteristics of wastewater after disinfection with peracetic acid," Water, Air, \& Soil Pollution, vol. 224, no. 10, article 1752, 2013.

[20] G. R. Finch, L. R. J. Liyanage, L. L. Gyurék, and J. S. Bradbury, Synergistic Effects of Multiple Disinfectants, AWWA Research Foundation and American Water Works Association, Denver, Colo, USA, 2000. 

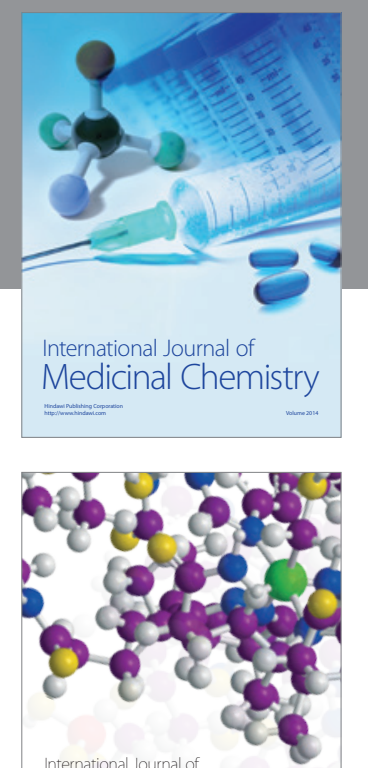

\section{Carbohydrate} Chemistry

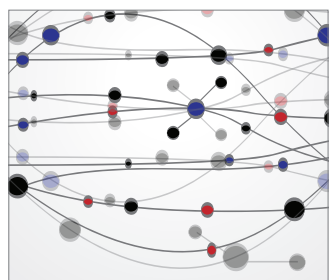

The Scientific World Journal
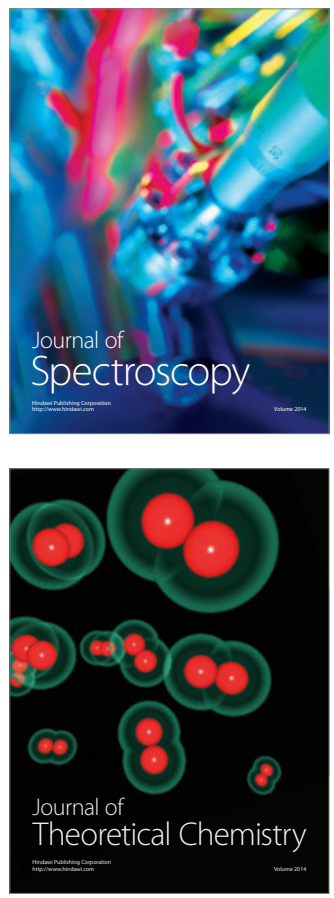
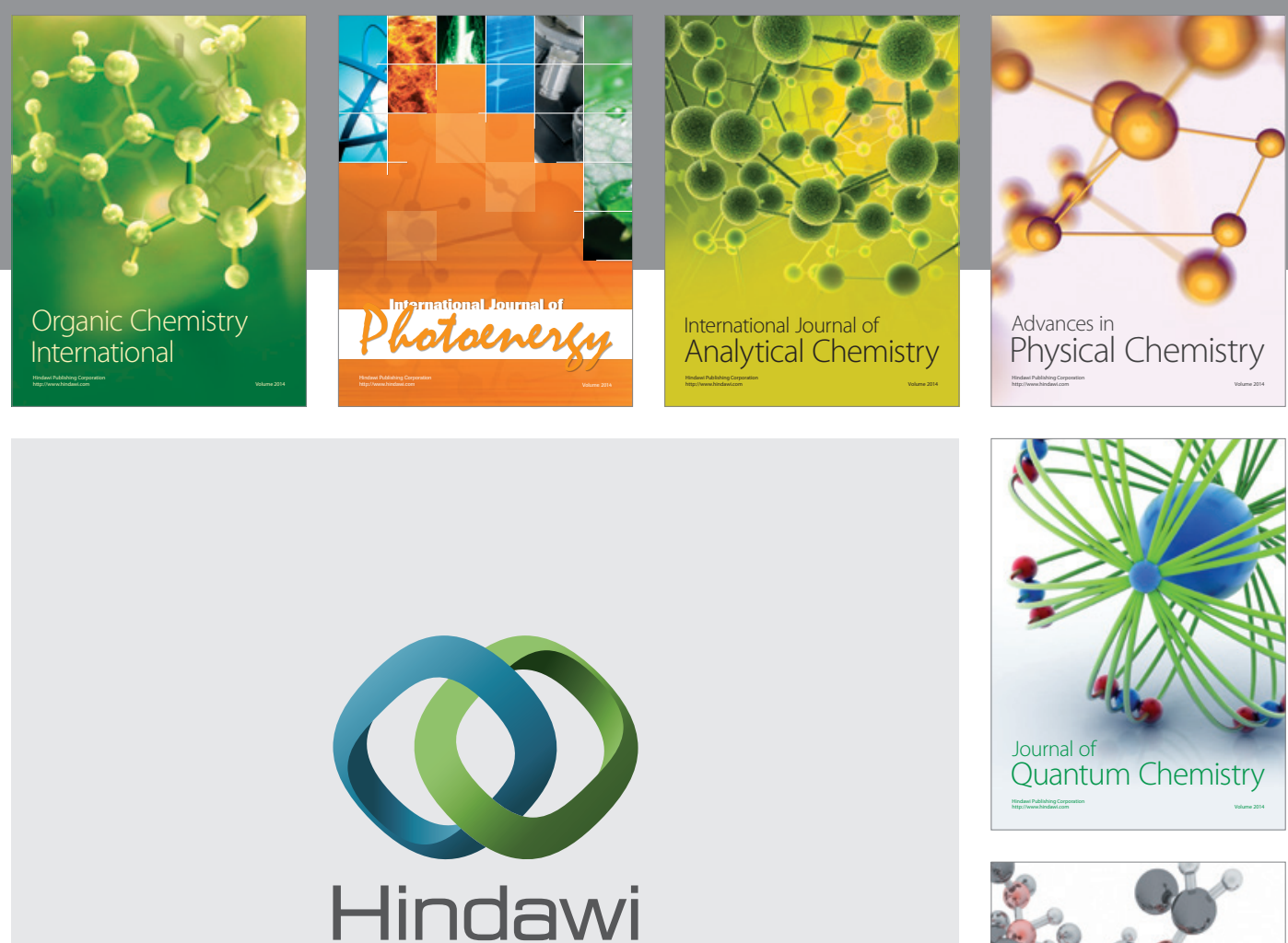

Submit your manuscripts at

http://www.hindawi.com

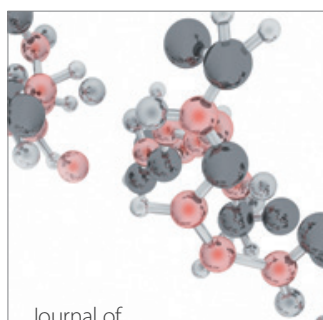

Analytical Methods

in Chemistry

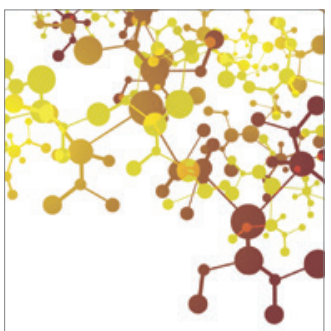

Journal of

Applied Chemistry

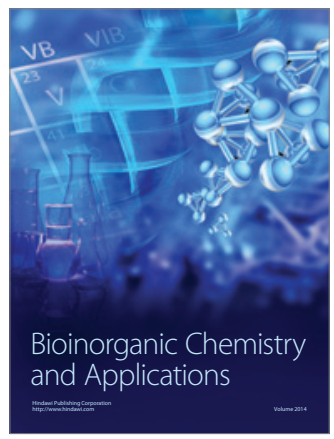

Inorganic Chemistry
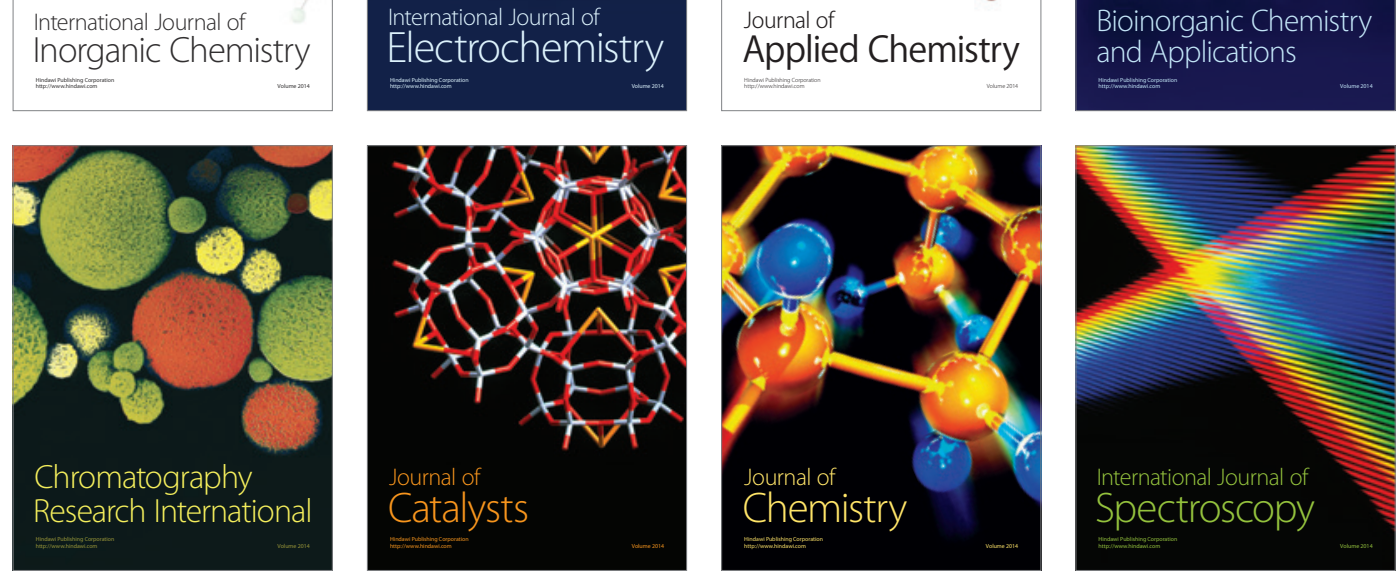